\title{
Geomorphological Characterization of Rivers Using Virtual Globes and Digital Elevation Data: A Case Study from the Naryn River in Kyrgyzstan
}

\author{
Betz, F., * Lauermann, M. and Cyffka, B. \\ Catholic University Eichstaett-Ingolstadt, Applied Physical Geography, Ostenstrasse 14, 85072 Eichstaett, \\ Germany, E-mail: florian.betz@ku.de
}

\begin{abstract}
:
In recent years, fluvial geomorphology included a range of new technologies for the characterization of riverine landscapes in the pool of methods. LIDAR, the analysis of drone imagery or satellite remote sensing improved the ability to analyze river systems in manifold ways. However, the high demand for (often expensive) data and processing skills limit the application commonly to smaller study reaches or to regions where data is already available. In contrast, a range of conceptual frameworks for the geomorphological characterization of river systems highlights the relevance of integrating the catchment scale context. Against this background, virtual globes such as Google Earth are cost-efficient alternatives as they make high resolution satellite imagery available almost worldwide. Merging the information mapped from virtual globes with digital elevation data allows the interpretation of riverscape attributes in the context of the longitudinal profile. In our study, we present the geomorphological mapping of the more than $600 \mathrm{~km}$ long Naryn River in Kyrgyzstan based on different virtual globes and the SRTM-1 digital elevation model. The experience from this mapping exercise suggests that the combination of virtual globe imagery and elevation data is a powerful and cost-efficient approach for river research and application in the context of data-scarce river corridors.
\end{abstract}

\section{Introduction}

In modern river science, it has become generally accepted to see rivers from a system point of view. This is a perspective which has also become popular as riverscape approach (Fausch et al., 2002). Over the past decades, a range of conceptual frameworks for the characterization of rivers has been proposed (see Gurnell et al., 2016b for a recent review). Despite the theory seeing rivers as hierarchical systems with various nested scales, empirical data has mostly been gained from either highly localized experiments or spatially loose studies (Marcus and Fonstad, 2008 and Fonstad and Marcus, 2010). More recently, technological progress allowed the acquisition of spatially consistent information on the catchment scale. While the visual interpretation of aerial imagery has already a certain tradition, the use of LIDAR, drones, and high resolution satellite imagery is a development of recent years (Tomsett and Leyland, 2019). Progress has been made for instance in the automated analysis of digital elevation models for river characterization (Roux et al., 2015 and Betz et al., 2020) but also in the processing of high resolution multispectral satellite imagery (Carbonneau et al., 2012). Even if these methods have an enormous potential for the analysis of riverscapes, the necessary datasets tend to be expensive as well as resource demanding in acquisition and processing. Especially in the context of developing countries they are often not available at all (Schmitt et al., 2014 and Betz et al., 2018, 2020). In such situations, the imagery available from virtual globes such as Google Earth can help to solve the issue of insufficient data availability. As early as 2006, Google Earth became available online and scientist started to discover the power of such virtual globes for studying the earth (Butler, 2006 and Tooth, 2006). While these early publications mainly focused on the educational potential of virtual globes, later research used such datasets for entire studies. For instance Fisher et al., (2013) used data from Google Earth to determine channel widths across a catchment. Perhaps the most sophisticated example of using virtual globe data for the study of entire rivers has been published by Large and Gilvear (2015) who assessed ecosystem services solely based on landscape attributes extracted by visual interpretation of Google Earth imagery. Beside the findings about the river ecosystem services they could successfully demonstrate how to get information about a riverine landscape from virtual globes.

The goal of this study is to develop a workflow for the characterization of riverscapes based on a combination of virtual globe imagery and digital 
elevation data. We test this framework at the example of the Naryn River in Kyrgyzstan and present an analysis of this more than $600 \mathrm{~km}$ long river. We discuss relevant theoretical issues related to the use of virtual globe data and suggest a costefficient and simple approach for the geomorphological characterization of rivers.

\section{Material and Methods}

\subsection{Study Area}

The Naryn River is located in Kyrgyzstan within the Tian Shan Mountains (Figure 1). The segment we focus on in this study begins in the uppermost headwaters of the Naryn in an elevation of $5133 \mathrm{~m}$. On the first approx. $266 \mathrm{~km}$ it is still named Big Naryn before its confluence with the Small Naryn in an elevation of $2300 \mathrm{~m}$. From there, the river is officially named "Naryn" and flowing to the west towards the Toktogul Reservoir where the first dam is located. At the dam, our area of interest is ending. Along this $752 \mathrm{~km}$ long river segment, the Naryn River is in a natural state without embankments or relevant modifications of the discharge regime (Betz et al., 2018 and Chymyrov et al., 2018). The climate is highly continental with mean annual summer temperatures up to $25^{\circ} \mathrm{C}$ and winter averages below $-25{ }^{\circ} \mathrm{C}$. The precipitation has an average annual amount of $300 \mathrm{~mm}$ and reaches a maximum in May and June. Due to these climatic conditions, the Naryn River is highly dependent on water supply from the glacier melt (Kriegel et al., 2013). This leads to a glacial discharge regime with a single peak in July. Mean annual discharge at the station Naryn City is $92.12 \mathrm{~m}^{3} / \mathrm{s}$ increasing to $323.33 \mathrm{~m}^{3} / \mathrm{s}$ at the inflow of the Toktogul Reservoir.
The entire region is highly influenced by the active tectonics of the Tian Shan. Several faults cross this mountain belt causing an interplay of mountain ranges and basins in the region with an east-west strike direction (Thompson et al., 2002). The Naryn Basin - the central part of the Naryn Catchment - is the biggest basin in the Kyrgyz Tian Shan. During the Pleistocene and Quaternary, terraces have formed in this basin with a height up to $20 \mathrm{~m}$ (Thompson et al., 2002). Even if their geological history is not fully understood, they are an important geomorphological feature. Further downstream, the Naryn is turning northwards. Here, the river is leaving the Naryn Basin and passing a water gap towards the Toktogul.

\subsection{Data Analysis}

First step of our data analysis is the extraction of a channel network from the SRTM-1 DEM. This dataset has a spatial resolution of 1 arc second resulting in a pixel size of $24.05 \times 24.05 \mathrm{~m}$ when projecting to UTM. We use the r.stream toolkit implemented in Grass GIS (Jasiewicz and Metz, 2011). Beside the channel network extraction, this toolkit allows also the computation of the stream order and the subsequent extraction of the main river course (Hack order $=1$ ). The resulting line is than split into segments fitting to the cells of the SRTM-1 elevation model and attribute fields for the desired mapping attributes have been added. This line was than loaded to QGIS which allows the integration of various virtual globe imagery via the QuickMapServices plug-in (www.qgis.org).

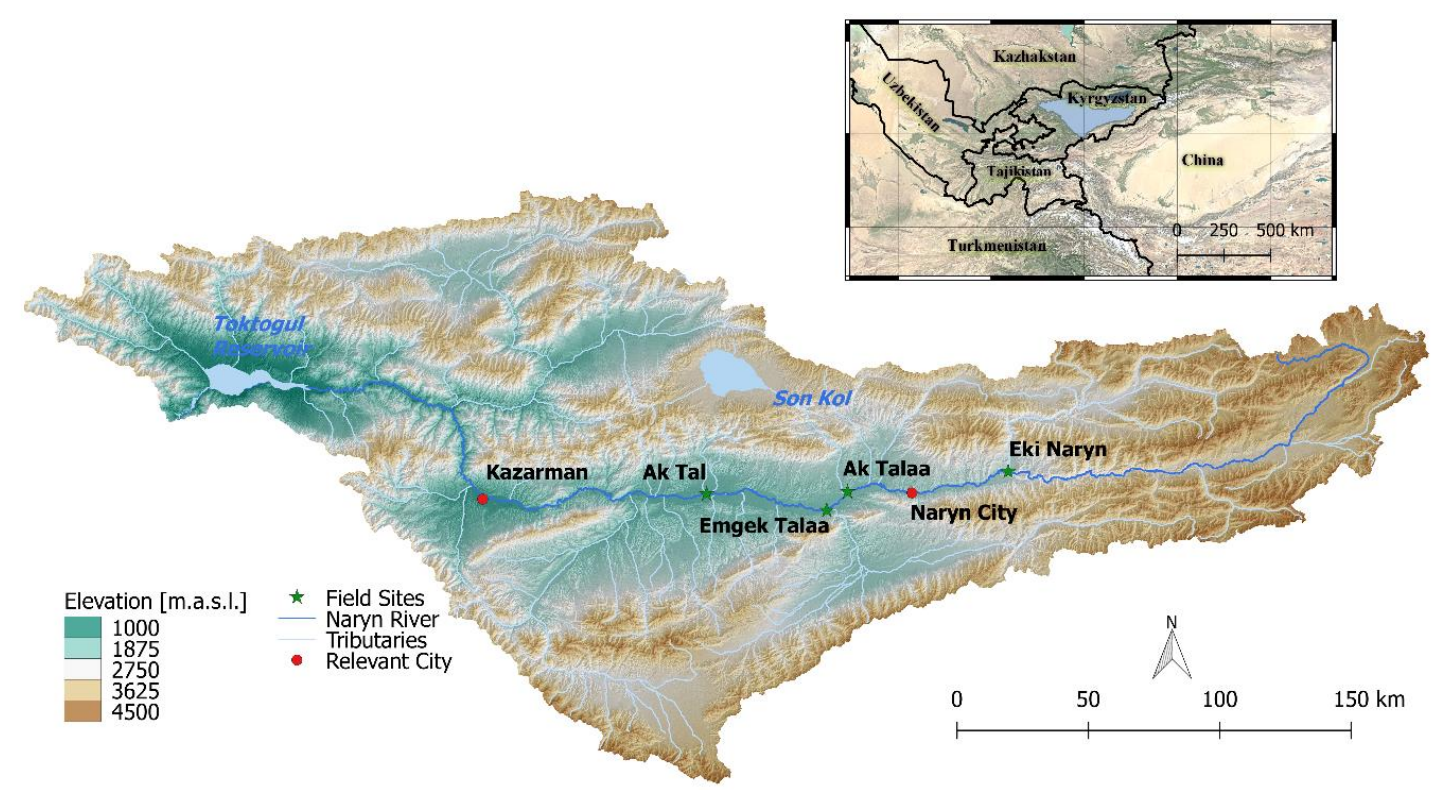

Figure 1: Overview over the study area; the light blue area in the inlet map gives the Naryn catchment 
Table 1: Attributes used for characterizing the Naryn River

\begin{tabular}{|l|l|l|}
\hline Characteristic & Specification & Distinguishing Attribute \\
\hline Valley Setting & Confined & $\begin{array}{l}\text { Majority of the channel hits the valley margin or } \\
\text { the terrace }\end{array}$ \\
\hline Floodplain & Laterally unconfined & $\begin{array}{l}\text { A minor share of the channel hits the valley } \\
\text { margin or the terrace, often on just one side }\end{array}$ \\
\hline & No floodplain & $\begin{array}{l}\text { No floodplain is present } \\
\text { margin or the terrace }\end{array}$ \\
\hline & Discontinuous floodplain & Floodplain is only present along one river bank \\
\hline River Type & Continuous floodplain & Floodplain is abundant on left and right bank \\
\hline & Gorge & Bedrock confined valley setting \\
\hline & Straight & $\begin{array}{l}\text { Low sinuosity with no extensive instream } \\
\text { features and absent or discontinuous floodplains }\end{array}$ \\
\hline & $\begin{array}{l}\text { Low sinuosity with extended gravel bars or } \\
\text { islands, clearly identifiable main channel }\end{array}$ \\
\hline & $\begin{array}{l}\text { Low sinuosity with multiple channel; single } \\
\text { channels show characteristics of braided rivers } \\
\text { with extended bars and islands }\end{array}$ \\
\hline & $\begin{array}{l}\text { Low sinuosity with confined valley setting; } \\
\text { instream geomorphic features like bars or islands } \\
\text { as well as floodplains are widely absent }\end{array}$ \\
\hline
\end{tabular}

We used imagery from Google Earth, Bing Maps and Yandex Maps for mapping riverscape attributes of the Naryn River. Using images from different virtual globes ensured the availability of cloudless high resolution imagery throughout the entire area of interest. This was not achievable by any of the single virtual globes mentioned above. Based on the river type, we discriminated also single reaches defining a reach boundary as a change in the river type. This reflects the assumption that there is a clear linkage between the controlling processes and the resulting river type (Fryirs and Brierley, 2013).

For the mapping itself, we base upon the Riverstyles Framework (Brierley and Fryirs, 2005) and assess confinement and the abundance of floodplains. Furthermore, we assign a river type as interpretation of the planform. Table 1 gives an overview of the attributes used during the mapping procedure. To integrate the elevation data in the interpretation of the mapping results, we computed a longitudinal profile from the extracted main river stem and the SRTM-1 DEM. As the profile shows some noise and errors probably resulting from radar scattering, we smooth the profile using constrained quantile regression smoothing (Schwanghart and Scherler, 2017 and Betz et al., 2020). This smoothed profile was also used to calculate average channel gradients for the different reaches. In addition to the profile and the gradients, we extracted also the flow accumulation along the longitudinal profile which can be used as proxy for the discharge. All analysis except the mapping have been performed using $R(R$ Core Team, 2015) along with GRASS GIS.

\section{Results}

\subsection{Planform Mapping}

Probably the most intuitive result for fluvial geomorphologist is the river type as this classification already includes a lot of interpretation. Figure 2 shows the distribution of river types along the entire Naryn River as well as for 4 selected sections. Based on the river type, we could discriminate 121 reaches with a median length of $2.25 \mathrm{~km}$. In the uppermost part of the catchment upstream from the confluence of Big and Small Naryn, steep headwater reaches dominate as shown in Figure 2a. Here the valley setting tends to be confined, floodplains are widely absent. Further downstream, there is an interplay of straight and braided reaches, also the valley setting changes between confined and partly confined. Floodplains are absent or occur in a discontinuous form (Figure $2 b)$. Further downstream, braided and braidedanastomising become the dominant river types (Figure 2c). In this setting, the valleys are likely to be unconfined, floodplains are mostly continuous. Another important feature of the lower part of the investigated catchment are two gorges with an entire length of more than $150 \mathrm{~km}$. Figure $2 \mathrm{~d}$ shows a part of the longer gorge. Within the gorges, the valley setting is confined, floodplains exist only in form of isolated pockets. Right downstream of the longer 
gorge, the Toktogul Reservoir begins. This river section has to be considered as heavily modified by human activities. Consequently, the valley setting as well as the floodplain abundance for the river type "reservoir" have been classified as "anthropogenic".

\subsection{River Characteristics along the Longitudinal Profile}

Often, the analysis of riverscape attributes along the longitudinal profile gives more insights than the planform interpretation alone. Figure 3 shows three major characteristics of the Naryn River along the longitudinal profile derived from the SRTM-1 elevation model. Along the uppermost $266 \mathrm{~km}$, the river is dominated by steep headwaters with reach averaged gradients up to $0.063 \mathrm{~m} / \mathrm{m}$. Despite the headwater character two plateaus with lower gradients exist within this river section. In the steep headwater reaches, floodplains are widely absent, only within the braided river sections on the lower gradient plateaus discontinuous floodplains exist. Downstream of the confluence of the Big and Small
Naryn, there is a $157 \mathrm{~km}$ long section characterized by an interplay of straight and braided reaches. The gradients are less steep compared to the steep headwaters and range from 0.0035 to $0.0043 \mathrm{~m} / \mathrm{m}$. For the majority of this section, the Naryn is partly confined by fluvial terraces. Floodplains exist mainly in a discontinuous form. Further downstream, the gradient becomes less steep with an average of $0.003 \mathrm{~m} / \mathrm{m}$. Dominant river types are braided and braided-anastomising. The Naryn is widely unconfined, only a minor share is partly confined. Floodplains are also abundant in a continuous form along the majority of this section. After this section, the Naryn flows into a short, 48 $\mathrm{km}$ long gorge with bedrock confined valley setting and absent floodplains before entering another section with braided river reaches. After this braided section, the Naryn enters another $115 \mathrm{~km}$ long gorge with occasional floodplain pockets before entering the Toktogul Reservoir. Within the gorges, the gradient is higher compared to the other river sections and reaches values up to $0.01 \mathrm{~m} / \mathrm{m}$.
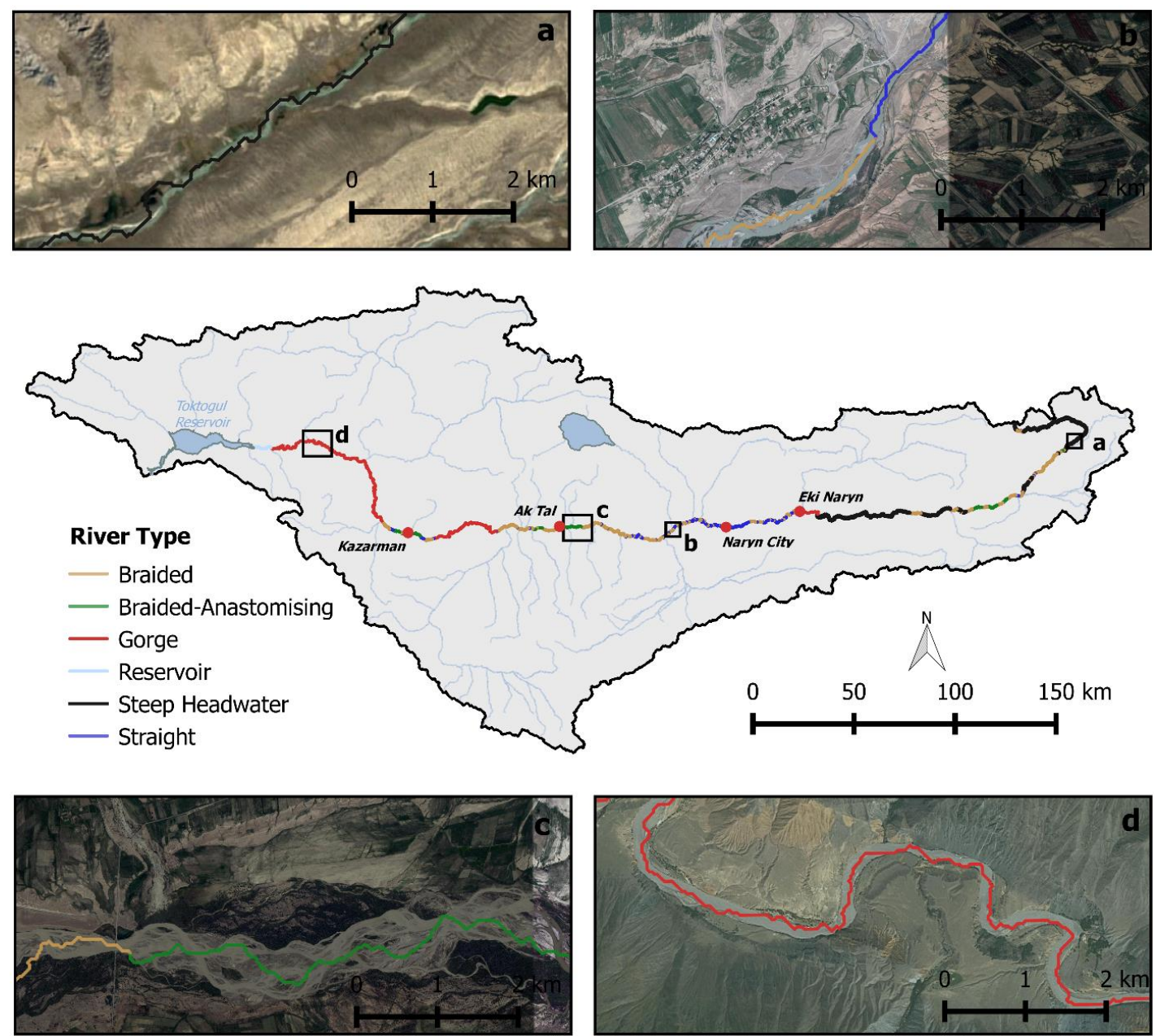

Figure 2: River types along the Naryn River 

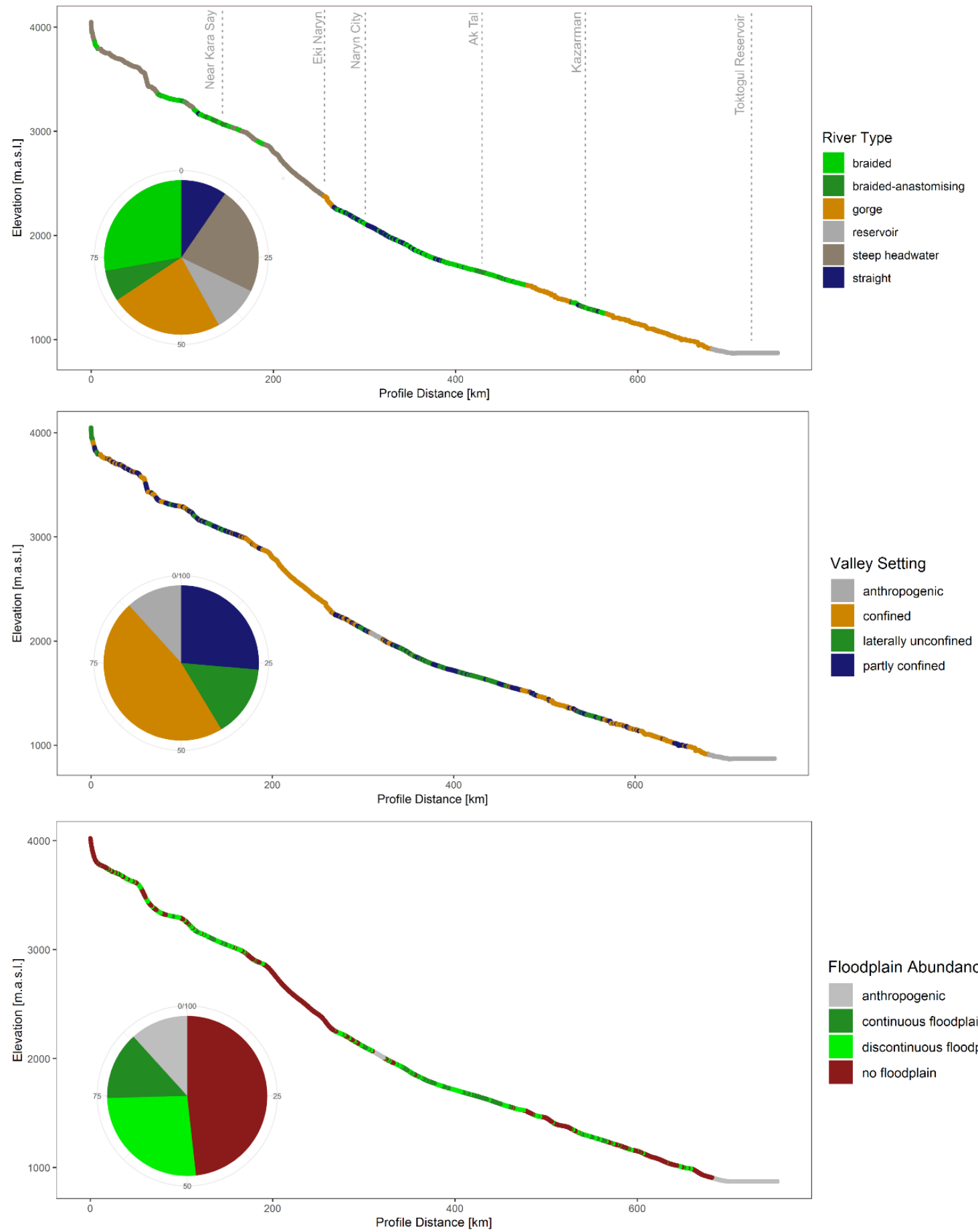

Floodplain Abundance

anthropogenic continuous floodplain discontinuous floodplain no floodplain

Figure 3: Major geomorphological characteristics along the Naryn River; the pie chart give the relative share of the respective riverscape attribute in percent

\section{Discussion}

\subsection{Disentangling the Geomorphology of the Naryn} River

Interpreting the heterogeneity of the Naryn River requires the analysis of the driving forces of the riverscape development. Besides the gradient, also discharge is considered as control of the river channel processes. To explore thresholds in the riverine landscape development, Church (2002) placed different channel types in the context of gradient and discharge. Figure 4 shows the river type in the context of gradient and flow accumulation in a similar manner as in the seminal paper of Church (2002). 
Steep headwaters are clearly associated with smaller flow accumulation (discharge) and high gradients while the Toktogul is clearly associated with the highest flow accumulation and the lowest gradient. The other river types are very close together in this plot indicating that there is a more complex control on the river type as just the available flow energy alone, a phenomenon being well-known also from other rivers in the world (Wohl, 2013). As a consequence of this complexity, the Naryn River shows a high diversity along the longitudinal profile. Despite this heterogeneity, 5 major segments can be discriminated (Figure 5).

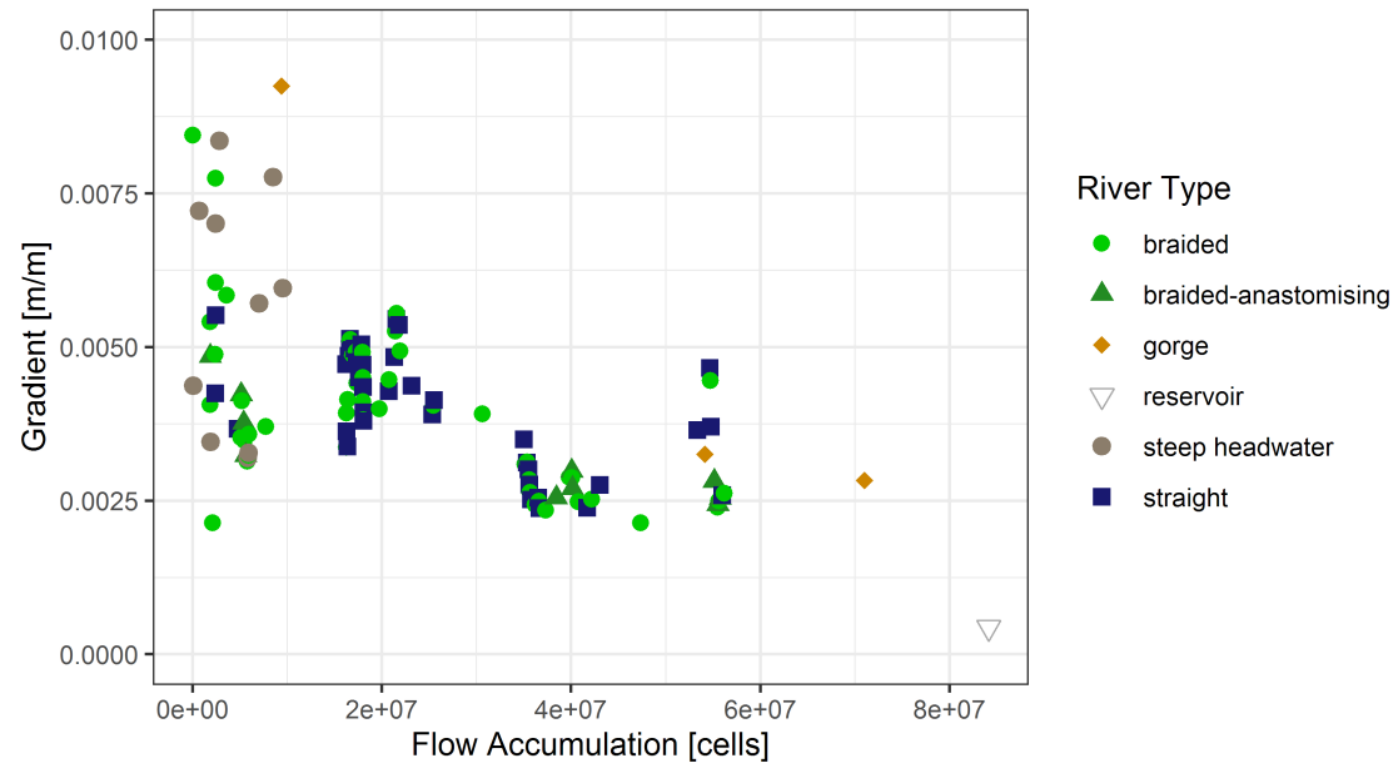

Figure 4: Relationship between channel gradient and flow accumulation as proxy for the discharge

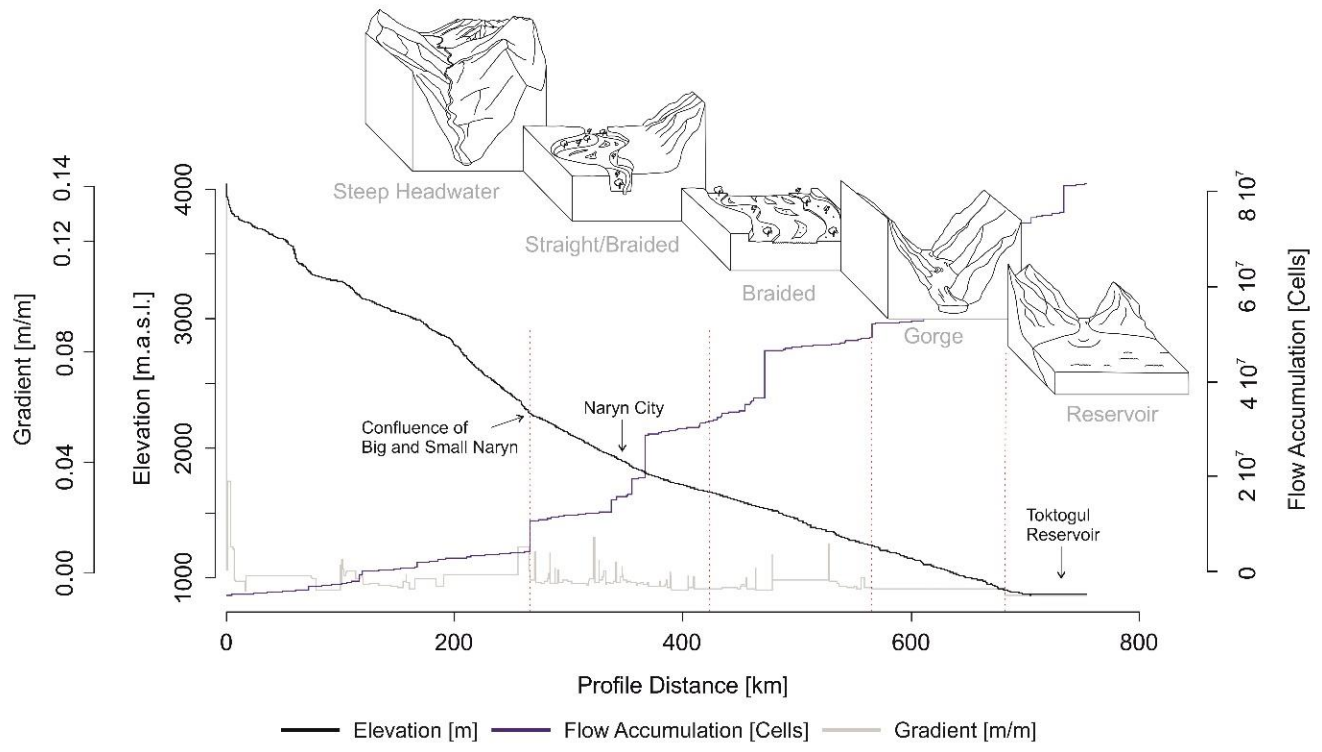

Figure 5: Generalized geomorphological structure of the Naryn River

The first segment is dominated by steep headwaters with a mainly confined valley setting without floodplains. Exceptions are two plateaus, where more gentle gradients allow the deposition of sediment and thus the formation of gravel bars and floodplains. In an overall interpretation, these headwater reaches can be seen as high energy system. Despite the available energy, the potential for lateral channel adjustment is low due to the confinement. Also other planform adjustment is not likely to happen as no instream features such as bars are abundant (Fryirs and Brierley, 2013). In the segment downstream from the confluence of Big and Small Naryn, the river flows into the Naryn 
Basin. The channel gradients become smaller due to this tectonic situation. As a consequence, sediments can be deposited and instream features like bars and islands develop. Also floodplains become abundant even if mainly in a discontinuous form. This segment is characterized by a deep incision of the Naryn in Quaternary sediments. The resultant terraces form a partly confined valley. Within the area actively shaped by the Naryn River, an interplay of straight and braided reaches dominate the riverscape. While for the confined, straight reaches we cannot expect extended planform changes, the braided reaches and their floodplains have a high potential for changes of the instream features as well as the channel margins. Further downstream, the channel gradient is getting gradually lower. Straight reaches do not occur anymore and braided as well as braided-wandering are becoming the dominant river types. This low gradient is leading to an extensive sediment deposition resulting in bars and islands as well as a wide, continuous floodplain in an unconfined valley setting. In this segment, the river has a high ability for planform adjustment as there is no confining margin for the majority of the flow length. In this setting, we can expect the riparian vegetation to be the main control of planform evolution as it has been demonstrated in various studies from other rivers (Gurnell et al., 2016a). In the downstream end, this segment has a sharp boundary where the Naryn River is leaving the Naryn Basin to the North and flowing into a $115 \mathrm{~km}$ long gorge. Within the gorge, floodplains as well as bars or islands are mostly absent even if occasional floodplain pockets are occurring. Consequently, planform adjustment is not likely to happen. Directly downstream from that gorge, the Toktogul Reservoir begins. Since the completion in 1971, the natural fluvial dynamics have been heavily modified by humans. Thus, the reservoir marks the end of the near natural part of the Naryn River.

From the context of gradient and flow accumulation (Figure 4), we see that these factors representing the flow energy of the river are not the only control over the river type. The local geology like e.g. the bedrock confinement in the gorges is the second important factor. Flow energy seems to be the primary control only within the tectonically formed Naryn Basin, where the straight, braided and braided-wandering reaches dominate. Straight reaches have higher gradients than the braided and braided-wandering reaches. However, all reaches are within a similar range. Thus, we can expect a certain sensitivity to change from one type to another as response to only small changes in discharge or sediment supply (Church, 2002).
However, further monitoring is necessary within the reaches in the Naryn Basin as also other factors like for instance the riparian vegetation or local grainsize variations might be controlling factors.

Interpreting the riverscape of the Naryn from a sediment dynamics perspective, we have full lateral and longitudinal connectivity under the current conditions. First barrier is the Toktogul Reservoir acting as sediment trap. While the steep headwaters with their connected hillslopes are likely to be a sediment source zone, the landforms of the braided segments in the central part of the catchment suggest sediment storage and re-distribution over shorter distances. In the gorge segment, we cannot expect extensive sediment storage, it is assumed to be a transfer zone.

\subsection{Virtual Globes as a Tool for Riverscape Characterization}

A wide range of information can be derived from virtual globes. However, there are several issues related to this data source. First, the data behind the imagery is not accessible for automated remote sensing approaches due to the web mapping service character of this data source. Therefore, visual interpretation is required what leads on the one hand to a high work load for the analyst. For instance, Fisher et al., (2013) used Google Earth for digitizing channel margins and report that they were able to digitize $10-25 \mathrm{~km}$ river length per hour while we have been able to map approx. $100 \mathrm{~km}$ per day applying our classification scheme. On the other hand, even if using well designed interpretation schemes, a certain degree of subjectivity is associated with the visual interpretation of imagery (Tadaki et al., 2014). Furthermore, there is no control of the imagery availability, an issue what was also recognized by Large and Gilvear (2015) for their ecosystem service based study. Especially for remote areas like the rural Kyrgyzstan where the overall interest in high quality satellite imagery is low, there exists not always up-to-date imagery. As a consequence, the mapping - at least over larger scales - has often to be performed on imagery from various dates in various seasons. An additional issue arises from imagery with different resolution. Thus we argue that it is necessary to focus on robust parameters widely independent from the acquisition date and the image resolution if the imagery source is not consistent across the entire area of interest.

Thus, even if Large and Gilvear (2015) could successfully demonstrate the derivation of manifold riverscape attributes from Google Earth, quantitative parameters are a critical issue when using virtual globes over larger areas. A simple example is the channel width. Here, it matters if the image is taken 
during a flood event with bordfull channels or in a low flow stage. Consequently, we suggest that a qualitative, interpreting approach (or in the sense of Brierley et al., 2013 "Reading the Landscape") is an appropriate method to avoid pitfalls arising from inconsistent imagery when applied by a trained fluvial geomorphologist. A combination of the information obtained from virtual globes with digital elevation data is a powerful combination to gain deeper insights into riverscapes. The possibility to place river attributes in the longitudinal profile or to see them in the context of channel gradient and flow accumulation as direct proxy for the discharge allows to evaluate potential flow energy thresholds in the river system. Despite the advantage of almost global availability, open access digital elevation data has limitations regarding resolution and accuracy. Thus, working with this kind of data requires some caution and results should be carefully evaluated.

\section{Conclusion}

Virtual globes make high resolution imagery available for almost any place in the world. This makes them a powerful tool for fluvial geomorphologist as they provide a vast quantity of data for no cost. Their high resolution allows to obtain a degree of detail not achievable with common medium resolution satellite data like pansharped Landsat $(15 \mathrm{~m})$ or Sentinel-2 data (10 $\mathrm{m})$. The fusion of the information from virtual globes with digital elevation data allows deeper insights in riverscapes as an interpretation of river attributes along the longitudinal profile becomes possible. Also further DEM derivations such as the channel gradient can be included in the analysis. However, there are clear limitations. Virtual globes do not allow to control the acquisition date of the imagery. Thus, quantitative analysis of morphometric parameters is limited due to the inconsistent base data. The same issue makes also a comprehensive analysis of change impossible.

Despite these limitations we could successfully demonstrate the geomorphological characterization of the Naryn River in Kyrgyzstan based on a qualitative mapping of riverscape attributes and the fusion of the resultant information with derivations from digital elevation data. This combination allows to expand our view on the riverscape of the Naryn from the plot or reach scale to the entire longitudinal profile. This gives interesting insights into the structure and functioning of this unique river system. Of course, virtual globes are not the exclusive tool for all kind of riverscape analysis and will never be able to substitute more sophisticated, quantitative methods. Nevertheless, they allow to move our view on rivers beyond the plot scale with simple methods and at low cost.

\section{References}

Betz, F., Lauermann, M. and Cyffka, B., 2018, Delineation of the Riparian Zone in Data-Scarce Regions Using Fuzzy Membership Functions: An Evaluation Based on the Case of the Naryn River in Kyrgyzstan. Geomorphology, Vol. 306, 170-181. Doi:10.1016/j.geomorph.2018.01.024.

Betz, F., Lauermann, M. and Cyffka. B., 2020, Open Source Riverscape: Open Source Riverscapes: Analyzing the Corridor of the Naryn River in Kyrgyzstan Based on Open Access Data. Remote Sensing Vol. 12, 2533. Doi: 10.3390/rs12162533.

Brierley, G. J. and Fryirs, K. A., 2005, Geomorphology and River Management. Applications of the River Styles Framework (Oxford: Wiley).

Brierley, G. J., Fryirs, K. A., Cullum, C., Tadaki, M., Huang, H. and Blue, B., 2013, Reading the Landscape: Integrating Theory and Practice of Geomorphology to Develop Place-Based Understandings of River Systems. Progress in Physical Geography Vol. 37(5), 601-621. doi:10.1177/0309133313490007.

Butler, D., 2006, The Web-Wide World. Nature, Vol. 439, 776-778.

Carbonneau, P., Fonstad, M. A., Marcus, W. A. and Dugdale, S. J., 2012, Making Riverscapes Real. Geomorphology Vol. 137, 74-86. doi:10.1016/j.geomorph.2010.09.030.

Church, M., 2002, Geomorphic Thresholds in Riverine Landscapes. Freshwater Biology, Vol. 47, 541-557.doi:10.1046/j.1365427.2002.00919.x

Chymyrov, A., Betz, F., Baibagyshov, E., Kurban, A., Cyffka, B. and Halik, U., 2018, Floodplain Forest Mapping with Sentinel-2 Imagery: Case Study of Naryn River, Kyrgyzstan. In Vegetation of Central Asia and Environs edited by D. Egamberdieva, M. Öztürk (Cham: Springer), 335-347.

Fausch, K. D., Torgersen, C. E., Baxter, C. V. and Li, H. W., 2002, Landscapes to Riverscapes: Bridging the Gaps Between Research and Conservation of Stream Fishes. BioScience, Vol. 52, 483-498. doi:10.1641/0006-3568(2002)052[0483:LTRBTG]2.0.CO;2.

Fisher, G. B., Bookhagen, B. and Amos, C. B., 2013, Channel Planform Geometry and Slopes from Freely Available High-Spatial Resolution Imagery and DEM Fusion: Implications for 
Channel Width Scalings, Erosion Proxies and Fluvial Signatures in Tectonically Active Landscapes. Geomorphology, Vol. 194, 46-56. doi:10.1016/j.geomorph.2013.04.011.

Fonstad, M. A. and Marcus, W. A., 2010, High Resolution, Basin Extent Observations and Implications for Understanding River Form and Process. Earth Surface Processes and Landforms, Vol. 35, 680-698. doi:10.1002/esp.1969.

Fryirs, K. A. and Brierley, G. J., 2013, Geomorphic Analysis of River Systems: An Approach to Reading the Landscape. (Oxford: WileyBlackwell).

Gurnell, A.M., Corenblit, D., Garcia de Jalon, D., Gonzales del Tanago, M., Grabowski, R.C., O’Hare, M.T., Szewczyk, M., 2016a, A Conceptual Model of VegetationHydromorphology Interactions within River Corridors. River Research and Applications, Vol. 32, 142-163. doi:10.1002/rra.2928.

Gurnell, A. M., Rinaldi, M., Belletti, B., Bizzi,, S., Blamauer, B., Braca, G., Buijse, A.D., Bessettini, M., Camenen, B., Comiti, F., Demarchi, L., Garcia de Jálon, D., Gonzáles del Tánago, M., Grabowski, R.C., Klösch, M., Lastoria, B., Latapie, A., Marcinkowski P., Martínez-Fernández, V., Mosselman, E., Mountford, J.O., Nardi, L., Okruszko, T., O'Hare, M.T., Palma, M., Percopo, C., Surian, N., van de Bound, W., Weissteiner, C., Ziliani, L., 2016b, A Multiscale Hierarchical Framework for Developing Understanding of River Behavior to support River Management. Aquatic Science, Vol. 78, 1-16. doi:10.1007/s00027-015-0424-5.

Jasiewicz, J. and Metz, M., 2011, A New GRASS GIS Toolkit for Hortonian Analysis of Drainage Networks. Computers and Geosciences, Vol. 37, 1162-1173. doi:10.1016/j.cageo.2011.03.003.

Kondolf, G. M., Piégay, H., Schmitt, L. and Montgomery, D. R., 2016, Geomorphic Classification of Rivers and Streams. In: Tools in Fluvial Geomorphology, edited by Kondolf, M., Piégay, H. (Chichester:Wiley-Blackwell), 133-158.

Kriegel, D., Mayer, C., Hagg, W., Vorogushyn, S., Duethmann, D., Gafurov, A. and Farinotti, D., 2013, Changes in Glacierisation, Climate and Runoff in the Second Half of the 20th Century in the Naryn Basin, Central Asia. Global and Planetary Change, Vol. 110, 51-61. doi:10.1016/j.gloplacha.2013.05.014.
Large, A. and Gilvear, D. J., 2015, Using Google Earth, A Virtual Globe Imaging Platform, for Ecosystem Services-Based River Assessment. River Research and Application, Vol. 31, 406421. doi:10.1002/rra.2798.

Marcus, W. A. and Fonstad, M. A., 2008, Optical Remote Mapping of Rivers at Sub-Meter Resolution and Watershed Extents. Earth Surface Processes and Landforms, Vol. 33, 424. doi:10.1002/esp.1637.

$\mathrm{R}$ Core Team, 2015, R: A Language and Environment for Statistical Computing. R Foundation for Statistical Computing. Vienna, Austria. URL: https://www.R-project.org.

Roux, C., Alber, A., Bertrand, M., Vaudor, L. and Piégay, H., 2015, Fluvial Corridor: A New ArcGIS Toolbox Package for Multiscale Riverscape Exploration. Geomorphology, Vol. 242, 29-37. doi:10.1016/j.geomorph.2014.04.018.

Schwanghart, W. and Scherler, D., 2017, Bumps in River Profiles: Uncertainty Assessment and Smoothing Using Quantile Regression Techniques. Earth Surface Dynamics, Vol.5, 821-839. Doi:10.5194/esurf-5-821-2017.

Schmitt, R., Bizzi, S. and Castelletti, A., 2014, Characterizing Fluvial Systems at Basin Scale by Fuzzy Signatures of Hydromorphological Drivers in Data Scarce Environments. Geomorphology, Vol. 214, 69-83. doi:10.1016/j.geomorph.2014.02.024.

Tadaki, M., Brierley, G. J. and Cullum, C., 2014, River Classification: Theory, Practice, Politics. Wiley Interdisciplinary Reviews: Water. doi:10.1002/wat2.1026.

Thompson, S. C., Weldon, R.J ., Rubin, C. M., Abdrakhmatov, K., Molnar, P. and Glenn, G., 2002, Late Quaternary Slip Rates Across the Central Tien Shan, Kyrgyzstan, Central Asia. Journal of Geophysical Research, Vol. 107. doi:10.1029/2001JB000596.

Tomsett, C. and Leyland, J., 2019, Remote Sensing of River Corridors: A Review of Current Trends and Future Directions. River Research and Applications, Vol. 35(7), 1:25. Doi: 10.1002/rra.3479.

Tooth, S., 2006, Virtual Globes: A Catalyst for the Re-Enchantment of Geomorphology? Earth Surface Processes and Landforms, Vol. 31, 1192-1194. doi:10.1002/esp.1383.

Wohl, E., 2013, The Complexity of the Real World tn the Context of the Field Tradition in Geomorphology. Geomorphology, Vol. 200, 5058. doi:10.1016/j.geomorph.2012.12.016. 